\title{
Serum tube identification of Candida albicans
}

\author{
D. W. R. MACKENZIE \\ From the Department of Microbiology, The Queen's University of Belfast
}

SYNOPSIS The production of filaments (germ tubes) by cells of Candida albicans in serum tubes permits presumptive identification to be made within two to three hours. The proportion of yeastlike cells forming filaments is progressively decreased with increasing cell concentration. The test is effective over a comparatively wide range of temperatures and using different types and concentrations of sera.

Routine identification of Candida albicans in diagnostic laboratories is usually dependent on the production on certain media of the characteristic refractile chlamydospores. Several other techniques have been described where the criteria are less specific, but which may have considerable practical value in permitting a rapid presumptive diagnosis. Such a test has been recently described by Taschdjian, Burchall, and Kozinn (1960), by which a rapid (two to three hours) provisional identification of $C$. albicans can be made by observing changes in the morphology of yeast cells in serum or serum derivatives. This paper deals with studies on the value of the 'serum tube' test in identifying C. albicans.

\section{MATERIAL AND METHODS}

YEASTS The following species of yeast capable of growth at $37^{\circ} \mathrm{C}$. were used in the investigations:-

One hundred and sixty-three isolates of C. albicans from seven diagnostic laboratories in the United Kingdom. All produced chlamydospores on Oxoid cornmeal agar.

C. brumptii, C. rugosa, C. utilis, Saccharomyces fragilis, and Schizosaccharomyces versatilis were obtained from the National Collection of Yeast Cultures; C. krusei, C. guilliermondii, C. macedoniensis, C. pseudotropicalis, C. stellatoidea from the Mycological Reference Laboratory, London School of Hygiene and Tropical Medicine; and C. tropicalis, Trichosporon capitatum, and Geotrichum $s p$. were isolated at this laboratory from human sources during routine mycological examinations.

TECHNIQUE The test organism is inoculated into $0.5 \mathrm{ml}$. of serum in a small tube or container (Kahn, Durham tube, Bijoux bottle), and incubated at $37^{\circ} \mathrm{C}$.

\section{RESULTS}

The rounded or short-oval cells of $C$. albicans Received for publication 30 May 1962. rapidly give rise to filamentous outgrowths and within two or three hours numerous 'hand mirror' forms (Hu, Livingood, Johnson, and Pomerat, 1954) are visible (Fig. 1). These are characteristic of $C$. albicans, and under appropriate conditions (see below) are produced by over $95 \%$ of the cells. They have been termed 'germ tubes' (Mackenzie, 1958; Taschdjian et al., 1960), thus emphasizing the close morphological similarities to the initial hypha of true filamentous fungi. Conditions affecting their formation have been studied as follows:

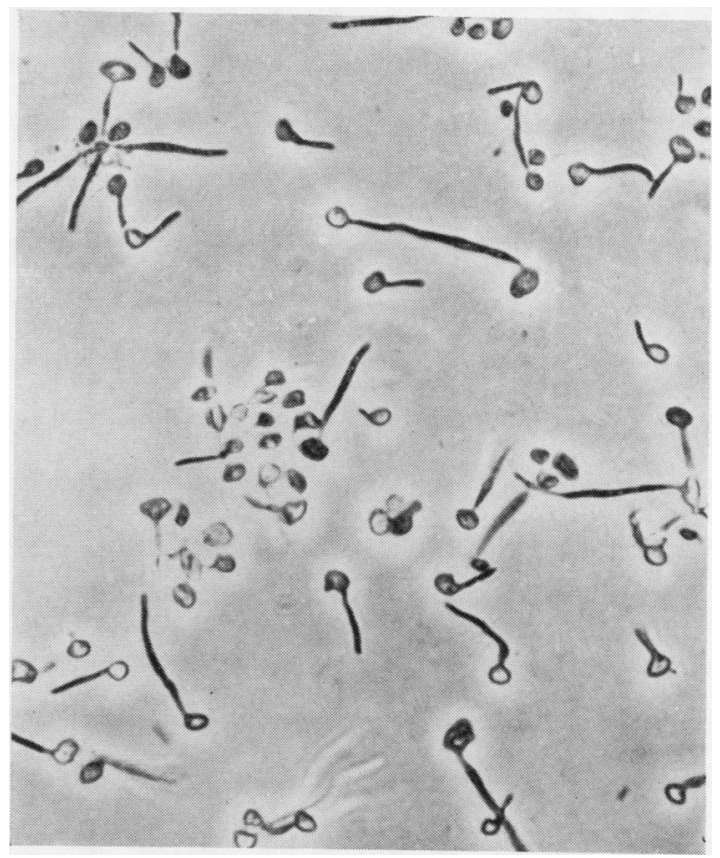

FIG. 1. Germ tubes of Candida albicans in bovine serum after three hours at $37^{\circ} \mathrm{C} . \times 640$. 


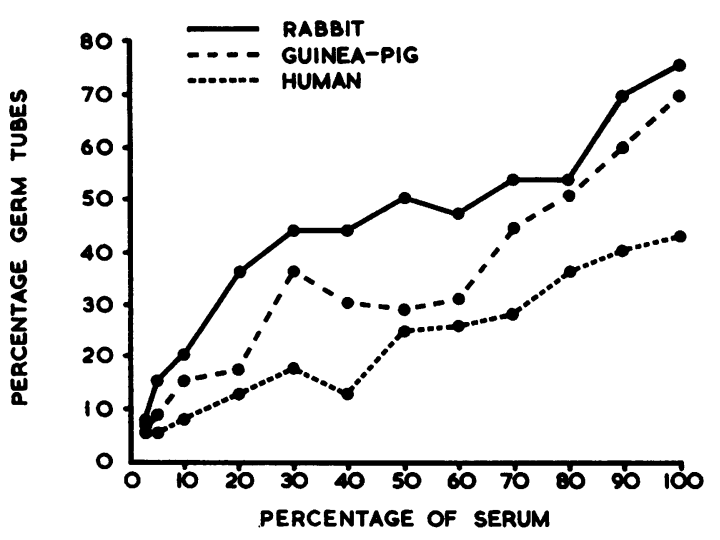

FIG. 2. Effect of serum concentration on production of germ tubes.

SERUM Taschdjian et al. (1960) reported that germ tubes were formed in fresh and inactivated human serum and in 'deep-frozen' stored material. Dog serum also proved satisfactory. These observations were confirmed and extended to include rabbit, guinea-pig, horse, and bovine sera. The duration and temperature of the storage of serum did not affect the incidence of germ tubes or their rate of appearance and subsequent development. They were not formed in heat-coagulated serum. With a standardized inoculum $\left(8 \times 10^{6}\right.$ cells $)$ and estimations of percentage germ tubes at each dilution based on counts of 500 cells, the incidence of filamentation is highest in undiluted serum and decreases with decreasing concentration of the serum (Fig. 2). The rapidity of the test makes sterilizing the glassware unnecessary.

INOCULUM The age of the inoculum is apparently not insignificant in determining the presence or absence of hyphal development. Cultures which had been stored at room temperature for up to six months formed germ tubes when they were inoculated into serum although the percentage of cells forming filaments naturally decreased as the cells became increasingly less viable.

In contrast, germ tube formation in serum is directly affected by the concentration of cells in the inoculum (Fig. 3). When the number exceeded $10^{7}$ per $\mathrm{ml}$. the incidence of germ tubes decreased until at concentrations of $5 \times 10^{8}$ cells per millilitre, and at greater concentrations they were virtually absent. The percentage of germ tubes derived from counts of 500 cells at each concentration after three hours at $37^{\circ} \mathrm{C}$., using fresh inactivated guinea-pig serum and a standardized volume of inoculum, and the relationship between length of strands and concentration of inoculum, are shown in Figure 3. Other sera tested showed a more marked inhibition? of germ tubes at high cell densities.

The concentration of cells required to suppress $\frac{\bar{\sigma}}{\bar{c}}$ germ tube formation by $50 \%$ was determined for $\frac{\text { त }}{\vec{*}}$ guinea-pig, bovine, and horse sera with the results $\varrho$ shown in Table I. If the inoculum of a serum tube

\section{TABLE I}

CONCENTRATION OF INOCULUM INHIBITING GERM TUBE FORMATION BY $50 \%$

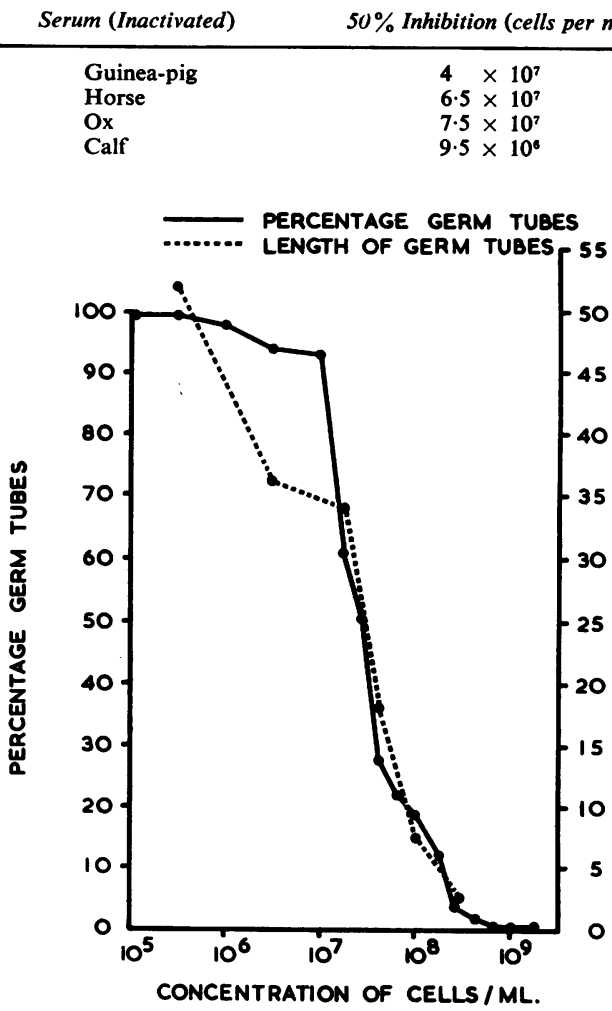

FIG. 3. Germ tube incidence and growth in relation to $\frac{D}{2}$ concentration of inoculum.

results in too great a concentration of yeast cells $N$ germ tube formation might be inhibited to the extent $\underset{\mathrm{C}}{\mathrm{N}}$ of invalidating the test. In practice, however, com- 0 plete inhibition is unlikely to be achieved although marked suppression is an established sequel to an excessively large inoculum.

Ten laboratory workers were asked to inoculate serum tubes from slant cultures of $C$. albicans, and ${ }^{\circ}$ the final concentration of cells was determined. This $\mathbb{\mathbb { D }}$ ranged from $2 \times 10^{6}$ to $6.4 \times 10^{7}$ cells per millilitre, $\frac{\mathcal{D}}{\Phi}$ corresponding to an anticipated incidence of germ tubes of 25 to $95 \%$ in most of the sera tested. Even 
at the lower figure, strand formation is sufficiently distinct to permit ready identification of $C$. albicans or C. stellatoidea. In one batch of calf serum, however, only $8 \%$ of cells in the inoculum formed strands at a concentration of $6.4 \times 10^{7}$ cells per millilitre. Clearly a $92 \%$ inhibition of germ tubes is undesirable and cannot be expected to give satisfactory results. When small quantities of serum are employed, there is a distinct possibility of the test being ineffectual. The best results are obtained when small quantities of inoculum are used, imparting no more than a faint turbidity to the serum substrate. Tests with common laboratory agar media (glucosepeptone, $2.5 \%$ malt extract, malt tellurite, blood, glucose-nutrient, and $2 \%$ peptone) showed no correlation between the percentage of germ tubes in serum and the type of medium supporting growth of the inoculum. Washing with normal saline before inoculation did not affect the ultimate percentage of germ tubes, and is considered to be unnecessary.

TEMPERATURE Tests performed between $30^{\circ} \mathrm{C}$. and $42^{\circ} \mathrm{C}$. at $1^{\circ}$ intervals showed that germ tubes were formed between $31^{\circ} \mathrm{C}$. and $41^{\circ} \mathrm{C}$.

SPECIFICITY The formation of filaments in serum or serum derivatives is, like the production of chlamydospores, characteristic of $C$. albicans but is not confined to this species alone. It has been noted in C. stellatoidea, C. utilis, C. rugosa, and Schizosaccharomyces fragilis, whilst the presence of elongated buds or pseudomycelial cells in inocula of C. brumptii and C. pseudotropicalis may mimic the germ tubes of $C$. albicans.

Specificity is relative, i.e., although the above species of yeasts form strands when grown in serum, they are (with the exception of $C$. stellatoidea) insignificant members of the population of sites likely to yield $C$. albicans. The value of the test lies in its rapidity and ease of execution, and it is best regarded as a screening test for yeasts of possible medical significance. It should be applied only to those isolates capable of growth at $37^{\circ} \mathrm{C}$. whose growth on primary isolation is essentially yeast-like, i.e., rounded, budding cells. Where microscopic examination shows the predominance of elongated or thread-like cells in young cultures it can be concluded that the isolate is not $C$. albicans.

\section{CONCLUSIONS}

It is concluded that serum tube tests permit a rapid presumptive diagnosis of $C$. albicans. Chlamydospore formation and biochemical characteristics (fermentation, assimilation, etc.) remain the specific criteria for positive identification and differentiation from other species of Candida. In a random series of 163 isolates identified as $C$. albicans in various laboratories in the United Kingdom, it was found that eight $(5 \%)$ failed to produce germ tubes and were shown by further investigation to be incorrectly identified. Although less rapid than agglutination tests with specific antisera, a positive result can nevertheless be obtained in two hours compared with overnight incubation which is required for the detection of chlamydospores.

This study was supported by a grant from the Medical Research Council. Acknowledgements are made of the technical assistance received from Mr. D. L. Corkin and Miss Lesley Rusk.

\section{REFERENCES}

Hu, F., Livingood, C. S., Johnson, Patricia, and Pomerat, C. M. (1954). A.M.A. Arch. Derm. Syph., 70, 1

Mackenzie, D. W. R. (1958). Studies on the Biology of Pathogenic Fungi. Ph.D. thesis, Edinburgh.

Taschdjian, Claire L., Burchall, J. J., and Kozinn, P. J. (1960). A.M.A. J. Dis. Child., 99, 212. 